\title{
Chronicles From The War On Young People: \\ Teaching Teens To Cope With Violence - The LOVE Photojournalism Project
}

\author{
Stanley Chasey \\ Concordia University
}

\begin{abstract}
This paper outlines and describes a community-based art educator's experience in an after school project that teaches photojournalism to adolescents whose lives have been affected by violence. Blending photography and writing the participants explore and document the issues surrounding violence in their personal lives as well as violence in the community. In addition, it identifies the personal transformation and the long-term impact on the life of the educator.
\end{abstract}

\section{Background}

This paper is informed by my personal experience as a co-founder and photography instructor of the Leave Out Violence (LOVE) Photojournalism Project. It is a report on previous work done as well as a consideration of work in progress. The organization Leave Out Violence (LOVE) was started in 1993 by Sheila Twinkle Rudberg whose husband Daniel was murdered by a 14 year-old in downtown Montreal in 1973. Mr. Rudberg witnessed a youth mugging a senior citizen and had pursued the boy. After cornering him Daniel Rudberg was stabbed and died instantly on the spot. Ms. Rudberg came to realize that the boy was also a victim in this tragic situation. During the court trial it came out during testimony that the boy had run away from the United States. His life there was one of drugs and gangs with little parental supervision and lots of exposure to violent movies and video games. In Montreal he pursued the same precarious lifestyle which eventually led him to commit the violent murder. It was clearly evident that proper guidance and little community support were lacking for most of this young man's life. Twenty years later, in 1993, Ms. Rudberg started LOVE as a community response helping young people to turn away from violence and realize the benefits of a violent free lifestyle.

In 1994, I was introduced to Ms. Rudberg and to my eventual partner in the project, Brenda Proulx, a professional journalist and journalism professor at Concordia University in Montreal. At the time I had been conducting research for my master's thesis about high school drop-outs and alternative education. As well I had begun to teach teens from local alternative high schools basic photography after school at Dawson College Institute of Photography. In January 1995 we launched the Leave Out Violence Photojournalism Project with 15 participants. This after-school projectis aimed at adolescents between the 13 and 18 years of age. Meeting twice a week after school in the photography facilities of Dawson College they are given cameras, paper and pens and are taught both basic photography and journalism skills. They are encouraged to explore and document the issues surrounding the personal violence that has affected their lives and the violence that surrounds them in the community. They go on to produce provocative photos and writings which have been on exhibition throughout Canada and the U.S. Most recently 
their work was featured at the Musee de Beaux-Arts de Montreal(Montreal Museum of Fine Arts). In addition, their work is published twice a year in their own newspaper called One Love and has been published in three books, L.O.V.E.works! (1998), The Courage To Change: A Teen Survival Guide (2001), and $L$ 'art de vivre sans violence (2002).

Since my involvement in the LOVE Photojournalism Project (PJP) I have experienced a remarkable personal transformation in terms of being an art teacher teaching in a community-based setting. Initially my intentions were to help participants discover photography by teaching them how to take pictures and learn basic photographic darkroom skills. As time went on I can reflect and realize that at various times I was not only a teacher but also a mentor, a social worker, counsellor, psychologist, facilitator, role model, and finally, a friend. Within this somewhat broad job description there was a need for me to gain a better understanding of this multi-disciplinary experience I was crossing in and out of while working with these young people trying to transform their own personal lives which had been affected by violence. It is from this context arises the main research problem for my on going study. How could I transform my teaching practice so that the youth participants would benefit from being involved in this community-based after school project aimed at helping them to overcome their prior experiences and go on to become valuable community members?

\section{Conceptual Framework}

Drawing from the fields of art education, adolescent development, social work, sociology and community development I attempted to understand the factors contributing to the personal transformation of both art teacher and the project participants. This interdisciplinary nature helps to form a conceptual foundation for inquiry into the research question.

I have been involved in the arts in one form or another since I was very young, first in music and then eventually branching out into photography, film-making and video. I remember my experience in the arts during my teen years as one that opened up a whole new way of looking at the world and provided me with the tools for self-expression at a time in life when being able to communicate your feelings and ideas goes a long way towards defining who you are, not only to yourself but also to your family, friends and the community to which we belong. Along with this experience I also became aware that with so many schools facing dwindling resources it is often the creative arts curriculum that takes a heavy loss in support from school administrators especially with the rise of computer technology. I think of the story related by Heather Robertson about the reformed technophile who has now become disillusioned by the crush of technology in the classroom. Now when he is invited to tour hi-tech schools and expected to be suitably impressed with the new computer lab, he asks only one question: "What did this room use to be?" Invariably, he says, he is told it was the music room, the stage, the art room, or the teachers' workroom. The answer gives him the only metaphor he needs 
(Robertson, 1998) as he laments the reduction of creative arts in the schools for computers

So, armed with my belief in the intrinsic value of teaching art to young people and the realization that opportunities for young people to pursue the arts seem to be dwindling in the public school system, I entered into a collaborative learning enterprise teaching photography for the first time to a group of adolescents some who were labelled as "at-risk" youth, and all were affected by violence in some way.

I first looked at the nature and function of the community art teacher in a communitybased setting. In the field of art education there has been an abundance of literature written about the art teacher in a regular school setting. The literature dealing with community art teachers teaching in community settings however has been somewhat less extensive. Did I really understand the word "community" when it was used? Looking closer at the notion of "community" I found that "community " means different things to different people. Central to the identification of a community is the shared consciousness of membership that unites its members. This shared consciousness may vary over time. It may be narrow and restricted, including only individuals who perceive themselves to be the same. Such a community might be called a community of sameness. On the other hand, individuals may acknowledge a shared membership with others who are different in various ways and thus see themselves as members of a community of difference (Hicks, 1994). In attempting to describe a community I became aware of the dualism inherent and fundamental to my understanding of what makes a community.

This notion of sameness and difference plays a significant role for the community art teacher in terms of teaching students art. In community-based art programs there is diversity in the type of students attracted to this kind of programming. It should be understood that the students are essentially shaped, defined, and defended by the communities in which they live and learn. Differences are rampant in geography, cultural origins, life-styles, resources, and the behaviours, beliefs, and values they generate-no matter where one lives. But for all the differences students encounter as they mature, they are ultimately shaped, if not bound, by similar perceptions, those shared experiences, events, and reasons that give a distinct form to the community in which they live (Baker, 1990).

The recognition of this idea of communities as being made up of differences as well as similarities is crucial to the success of any teacher teaching in any community. A community teacher develops the contextualized knowledge of culture, community, and identity of the children and their families as the core of their teaching practice (Foster, 1997; Ladson-Billings, 1994; Murrell, 2001). Community teachers see themselves as change agents, and despite their own less-than-empowering experiences in school, they see education as the key to success for the young people whom they serve. Most articulate a sense of commitment to their community- a sense of "giving back." (Murrell, 2000). In essence this describes my own personal evolution as an art educator as I became engaged in the LOVE Photojournalism Project. My acceptance of the idea of community as being made up of both differences and sameness ultimately filtered down 
to the community building approach I shared and emphasized to the teen participants I taught in the project.

My career as a photography teacher prior to working with the teens of the LOVE Photojournalism Project had been primarily teaching adult learners in a continuing education setting. I had no previous experience working with at-risk youth and I quickly realized that if I was to have any success with these kids I would have to become more familiar as well as more comfortable with this special population. I was fortunate enough to discover and learn about the Risk and Prevention Program at Harvard University. The Risk and Prevention Program is an interdisciplinary master's program drawing primarily from the fields of education, psychology, public health and social policy. It prepares child and youth care workers within a climate of dramatically shifting disciplinary boundaries. It is argued that practitioners working within this climate will benefit by grounding their practice in contemporary theories of child, youth and community development, particularly theories that provide broad and flexible explanations of the interactive nature of risk and resilience processes (Nakkula, Ayoub, Noam \& Selman, 1996). The discovery of this concept provided me with a better understanding of the direction I was heading into with my involvement with LOVE. My role was no longer that of just a photography teacher as my days began to involve making links with social services, school teachers and guidance counsellors, psychologists, police, foster families and group homes, a variety of community agencies and parents. As a result of my understanding of the purpose and function of these groupsI became better equipped to serve the teen participants as I entered into this collaborative learning enterprise.

At the outset of the project it immediately became apparent to me that defining the atrisk youth would prove to be difficult which in turn would make candidate selection difficult as well. I wondered what young person today was not "at-risk". Ironically there were also objections by the youth themselves to being labelled as "at-risk" because of the obvious negative stereotyping and limitations that the term brings forth to young people. Labels such as "at-risk" can serve to immobilize youth within the community by defining the young in terms of their perceived deficiencies, rather than their potential capacities (Kretzmann \& McKnight, 1993). However, evidence is accumulating that many adolescents face multiple risks in such diverse settings as the family, (e.g., abuse, neglect, parental discord and divorce), community (encounters with violence, drug use, and poor health conditions), peer world (e.g. delinquency, truancy, and excessive risktaking activity), and school environment (e.g. lack of resources, lack of adult support, and disorganization) (e.g., Werner,1990; Noam, Chandler, \& Lalonde, 1995).

Realizing that violence has no boundaries and that it affects us all I acknowledged the broad range of risks as significant factors to consider when selecting and interviewing prospective project participants. I came to understand that the violence that threatening today's children is old news, as is the decline in the quality of their education and the trials that weaken and destroy many of their families (Garbarino, Durbow, Kostleny, \& Carole, 1992; Hamburg, 1992). However, the consequences of these problems are always new to each child. As I enter into my ninth year of running the Photojournalism Project I think about all the stories I've been told and the images I've seen. I appreciate 
the uniqueness of each individual who produced them as well as the unique circumstances that brought them to me.

\section{Summary}

Like a wide angle lens, my teaching experience within the Photojournalism Project has been able to capture the trials and tribulations of being an adolescent in such a violent world. As the title suggest the chronicles I have heard and seen within the Project have been well documented by the teens themselves and yes, sometimes it does feel like there's a war against young people. As a community art teacher who has entered into this frontline collaboration, providing the tools necessary for self-expression has always been one of my main goals and it is from these tools we gain the understanding that change is possible.

Over the years I have been involved with the LOVE youth in various activities and I have been privileged to be a witness to their tremendous growth and strength as they go on to become valuable members of the community. As part of my continuing research I will be revisiting some of the LOVE youth and attempting to collaborate once more to retrace and articulate the process of their journey in coping with the violence in their lives. The opportunity to take a "then and now" snapshot of some of the project participants will provide a longitudinal element to the work I have done and hopefully encourage other art teachers and make them realize the positive and supporting role they can play in young people's lives.

\section{$\underline{\text { References }}$}

Baker, D.W. (1990). "Git Real”: On Art Education and Community Needs. Art Education. 43, 6, 41-49.

Foster, M. (1997). Black teachers on teaching. New York: New York Press.

Fradette, A. \& Mailloux, E. (Eds.). (2002). L'art de vivre sans violence. Outremont(Quebec): Les Editions internationals Alain Stanke.

Garbarino, J., Durbow, N., Kostleney, K., \& Carole, P. (1992). Children in danger: Coping with the consequences of community violence. San Francisco: Jossey-Bass.

Hamburg, D.A. (1992). Today's children: Creating a future for a generation in crisis. New York: Random House.

Hicks, Laurie E. (1994). Social Reconstruction and Community. Studies in Art Education. 35, 3, 149-156. 
Kretzmann, J.P \& McKnight, J.L. (1993) Building communities from the inside out. Chicago: ACTA Publications.

Ladson-Billings, G. (1994). The dreamkeepers: Successful teachers of African American children. San Francisco: Jossey-Bass.

Murrell, Peter C. (2000). Community teachers: A conceptual framework for preparing exemplary urban teachers. The Journal of Negro Education. 69, 4, 338-348.

Murrell, Peter C. (2001). The community teacher: $\underline{\text { A new framework for effective urban }}$ teaching. New York: Teachers College Press.

Nakkula, M., Ayoub, C., Noam, G.G., Selman R. (1996). Risk and Prevention: An Interdisciplinary Master's Program in Child and Adolescent Development. Journal of Child and Youth Care Work. 11, 9-31.

Noam, G.G., Chandler,M., \& Lalonde, C. (1995). Clinical-developmental psychology: Constructivism and social cognition in the study of psychological dysfunctions. In D. Cicchetti \& D.J. Cohen (Eds.), Developmental psychopathology, Vol. $1, \underline{\text { Theory }}$ and methods. New York: Wiley.

Proulx, B. (1998). L.O.V.E. works! Photojournalism by the Leave Out Violence Teens. Toronto: Stoddart.

Proulx, B. (2001). The courage to change. A teen survival guide. Toronto: Second Story Press.

Robertson, H. (1998). No more teachers, no more books: the commercialization of Canada's schools. Toronto: McClelland \& Stewart Inc.

Werner, E. (1990). Protective factors and individual resilience. In S. Meisels \& J. Shonkoff (Eds.), Handbook of early childhood intervention. Cambridge, MA: Cambridge University Press. 